\title{
Cyclooxygenase-2 Contributes to Functional Hyperemia in Whisker-Barrel Cortex
}

\author{
Kiyoshi Niwa, ${ }^{1}$ Eiichi Araki, ${ }^{1}$ Scott G. Morham, ${ }^{2}$ M. Elizabeth Ross, ${ }^{1}$ and Costantino ladecola ${ }^{1}$ \\ Center for Clinical and Molecular Neurobiology, Departments of Neurology and Neuroscience, University of Minnesota \\ Medical School, Minneapolis, Minnesota 55455, and 2Myriad Genetics, Salt Lake City, Utah 84108
}

The prostanoid-synthesizing enzyme cyclooxygenase-2 (COX-2) is expressed in selected cerebral cortical neurons and is involved in synaptic signaling. We sought to determine whether COX-2 participates in the increase in cerebral blood flow produced by synaptic activity in the somatosensory cortex. In anesthetized mice, the vibrissae were stimulated mechanically, and cerebral blood flow was recorded in the contralateral somatosensory cortex by a laser-Doppler probe. We found that the COX-2 inhibitor NS-398 attenuates the increase in somatosensory cortex blood flow produced by vibrissal stimulation. Furthermore, the flow response was impaired in mice lacking the COX-2 gene, whereas the associated increase in whisker- barrel cortex glucose use was not affected. The increases in cerebral blood flow produced by hypercapnia, acetylcholine, or bradykinin were not attenuated by NS-398, nor did they differ between wild-type and COX-2 null mice. The findings provide evidence for a previously unrecognized role of COX-2 in the mechanisms coupling synaptic activity to neocortical blood flow and provide an insight into one of the functions of constitutive COX-2 in the CNS.

Key words: cerebral blood flow; somatosensory activation; glucose use; prostanoids; 2-deoxyglucose; COX-2 knock-out mice; NS-398
Cyclooxygenase-2 (COX-2) is an enzyme involved in the synthesis of prostaglandins and thromboxanes from arachidonic acid (for review, see Vane et al., 1998). In some organs, COX-2 is not present in the normal state, but its expression is induced by inflammatory stimuli or mitogens (for review, see Dubois et al., 1998). In brain, however, COX-2 is constitutively expressed and is localized to a restricted population of excitatory neurons, wherein it is enriched in dendritic arborizations and spines (Yamagata et al., 1993; Breder et al., 1995; Kaufmann et al., 1996). The role that COX-2 plays in normal brain function has yet to be elucidated. In the adult cerebral cortex, neuronal COX-2 expression is upregulated by synaptic activity (Yamagata et al., 1993) and, in the developing nervous system of the rat, COX-2 expression increases at a time when activity-dependent synaptic remodeling occurs (Kaufmann et al., 1996). These observations, in concert with its synaptic localization, have suggested that COX-2 is involved in activity-dependent processes and synaptic signaling (Kaufmann et al., 1996).

Synaptic activity is one of the critical factors controlling the distribution of cerebral blood flow (CBF) among the different brain regions. Thus, regional $\mathrm{CBF}$ is dynamically regulated to closely match the changes in functional activity of each brain region (for review, see Raichle, 1987; Woolsey et al., 1996). For example, when neural activity increases in the somatosensory or visual cortex, the amount of flow reaching these regions increases in proportion to the degree of activation (Fox and Raichle, 1984;

\footnotetext{
Received Sept. 13, 1999; revised Oct. 14, 1999; accepted Nov. 1, 1999.

This work was supported by National Institutes of Health Grants NS35806 and NS38252. C.I. is the recipient of a Javits Award from National Institutes of Health/ National Institute of Neurological Disorders and Stroke. The editorial assistance of Deborah Kabes is gratefully acknowledged.

Correspondence should be addressed to Dr. C. Iadecola, Department of Neurology, University of Minnesota, Box 295, University of Minnesota Health Center, 420 Delaware Street SE, Minneapolis, MN 55455. E-mail: iadec001@tc.umn.edu. Copyright (C) 2000 Society for Neuroscience $0270-6474 / 00 / 200763-08 \$ 15.00 / 0$
}

Ginsberg et al., 1987; Greenberg et al., 1979) (for review, see Raichle, 1987). The spatial and temporal correspondence between neural activity and $\mathrm{CBF}$ is so accurate that changes in $\mathrm{CBF}$ are routinely used to map brain function in humans (Raichle, 1998). Although the mechanisms that link synaptic activity to local blood flow have been investigated for over a century, they still remain to be elucidated in full (Lou et al., 1987; Iadecola, 1993; Woolsey et al., 1996). The observation that COX-2, an enzyme whose reaction products are vasoactive (Ellis et al., 1979; Leffler and Busija, 1987; Wei et al., 1996), is closely associated with postsynaptic elements of excitatory neurons, raises the possibility that COX-2 plays a role in the mechanisms coupling synaptic activity to blood flow in brain.

In the present study, we sought to determine whether COX-2 is involved in the increases in CBF that accompany neural activity. Using activation of the rodent whisker-barrel cortex as a model of functional hyperemia (Greenberg et al., 1979; Woolsey and Rovainen, 1991), we found that the selective COX-2 inhibitor NS-398 attenuates the increase in neocortical blood flow produced by vibrissal stimulation. Furthermore, the hyperemic response is impaired in mutant mice lacking COX-2, whereas the associated increase in glucose use, a variable that reflects neural activity, is not affected. The findings unveil a previously unrecognized role of COX-2 in the mechanisms linking synaptic activity to local blood flow in the somatosensory cortex and provide an insight into one of the potential functions of COX-2 in the normal brain.

\section{MATERIALS AND METHODS}

\section{Animals}

C57BL/6 mice were obtained from The Jackson Laboratory (Bar Harbor, Maine). COX-2 null mice [homozygous $(-/-)$ mice and their wild-type $(+/+)$ littermates] were obtained from a colony established at the University of Minnesota from breeding pairs provided by one of the authors (S. Morham) (Morham et al., 1995). Mice were back-crossed to 
Table 1. Arterial pressure and blood gases in the mice studied

\begin{tabular}{|c|c|c|c|c|c|}
\hline & \multicolumn{5}{|c|}{ Effect of NS -398 on cerebrovascular regulation } \\
\hline & $\begin{array}{l}\text { MAP } \\
(\mathrm{mmHg})\end{array}$ & $\begin{array}{l}\mathrm{pCO}_{2} \\
(\mathrm{mmHg})\end{array}$ & $\begin{array}{l}\mathrm{pO}_{2} \\
(\mathrm{mmHg})\end{array}$ & $\mathrm{pH}$ & $n$ \\
\hline \multicolumn{6}{|l|}{ Vibrissal stimulation, $\mathrm{ACh}$} \\
\hline Ringer's & $86 \pm 5$ & $33.9 \pm 0.5$ & $129.1 \pm 4.7$ & $7.35 \pm 0.02$ & \\
\hline NS-398 & $78 \pm 4$ & $35.6 \pm 0.4$ & $113.5 \pm 1.9$ & $7.30 \pm 0.03$ & \\
\hline \multicolumn{5}{|l|}{ BK } & $6 \#$ \\
\hline Ringer's & $85 \pm 2$ & $34.4 \pm 0.4$ & $131.8 \pm 3.1$ & $7.33 \pm 0.02$ & \\
\hline NS-398 & $84 \pm 4$ & $34.1 \pm 0.3$ & $129.7 \pm 8.7$ & $7.31 \pm 0.03$ & \\
\hline \multicolumn{5}{|l|}{ Hypercapnia } & $6 \#$ \\
\hline Ringer's & $88 \pm 4$ & $54.5 \pm 0.5^{*}$ & $132.9 \pm 7.4$ & $7.18 \pm 0.02 *$ & \\
\hline \multirow[t]{3}{*}{ NS-398 } & $83 \pm 2$ & $54.6 \pm 0.8^{*}$ & $123.8 \pm 7.9$ & $7.15 \pm 0.02 *$ & \\
\hline & \multicolumn{5}{|c|}{ Cerebrovascular regulation in $\mathrm{COX}-2$ null mice } \\
\hline & $\begin{array}{l}\text { MAP } \\
(\mathrm{mmHg})\end{array}$ & $\begin{array}{l}\mathrm{pCO}_{2} \\
(\mathrm{mmHg})\end{array}$ & $\begin{array}{l}\mathrm{pO}_{2} \\
(\mathrm{mmHg})\end{array}$ & $\mathrm{pH}$ & $n$ \\
\hline \multicolumn{5}{|l|}{$\mathrm{COX}-2+/+$} & 6 \\
\hline Vibrissal stimulation & $81 \pm 3$ & $34.1 \pm 0.7$ & $141.1 \pm 2.4$ & $7.33 \pm 0.02$ & \\
\hline $\mathrm{ACh}, \mathrm{BK}$ & $79 \pm 3$ & $35.4 \pm 0.6$ & $124.2 \pm 3.5$ & $7.30 \pm 0.03$ & \\
\hline Hypercapnia & $78 \pm 3$ & $54.6 \pm 1.2^{*}$ & $132.1 \pm 5.3$ & $7.16 \pm 0.03^{*}$ & \\
\hline \multicolumn{5}{|l|}{ COX $-2-1-$} & 6 \\
\hline Vibrissal stimulation & $85 \pm 3$ & $34.1 \pm 0.7$ & $135.2 \pm 3.1$ & $7.33 \pm 0.03$ & \\
\hline $\mathrm{ACh}, \mathrm{BK}$ & $80 \pm 7$ & $34.6 \pm 0.6$ & $119.0 \pm 3.7$ & $7.31 \pm 0.02$ & \\
\hline Hypercapnia & $79 \pm 3$ & $56.2 \pm 0.5^{*}$ & $135.7 \pm 4.0$ & $7.19 \pm 0.02 *$ & \\
\hline
\end{tabular}

Cerebral glucose use during vibrissal stimulation in COX-2 null mice

\begin{tabular}{|c|c|c|c|c|c|c|}
\hline & $\begin{array}{l}\text { MAP } \\
(\mathrm{mmHg})\end{array}$ & $\begin{array}{l}\mathrm{pCO}_{2} \\
(\mathrm{mmHg})\end{array}$ & $\begin{array}{l}\mathrm{pO}_{2} \\
(\mathrm{mmHg})\end{array}$ & $\mathrm{pH}$ & $\begin{array}{l}\text { Plasma glucose } \\
(\mathrm{mg} / \mathrm{dl})\end{array}$ & $n$ \\
\hline COX $-2+/+$ & $101 \pm 4$ & $32.3 \pm 2.1$ & $102.1 \pm 2.2$ & $7.30 \pm 0.02$ & $160.3 \pm 17.2$ & 6 \\
\hline $\mathrm{COX}-2-1-$ & $106 \pm 4$ & $34.7 \pm 0.9$ & $97.9 \pm 1.9$ & $7.29 \pm 0.02$ & $152.5 \pm 20.5$ & 6 \\
\hline
\end{tabular}

Mean $\pm \mathrm{SE} ;{ }^{*} p<0.05$, from respective control; \#, BK and hypercapnia were tested in the same mice. MAP, Mean arterial pressure.

C57BL/6 mice six to eight times and were studied at age 2-3 months. Experiments were performed in age-matched littermates $(\mathrm{COX}-2+1+$ and $-/-)$ to minimize confounding effects deriving from the genetic background of the mice. The genotype of all COX-2 mice was determined by PCR (Morham et al., 1995). COX-2 mRNA is not detectable in the brain of COX-2 -/- mice (C. Iadecola, S. Morham, and M. E. Ross, unpublished observations).

\section{Cerebral blood flow during vibrissal stimulation}

Techniques used for studying the cerebral circulation in mice were similar to those described previously (Zhang et al., 1997; Yang et al., 1998; Iadecola et al., 1999). Mice were anesthetized with urethane (750 $\mathrm{mg} / \mathrm{kg}$ ) and chloralose $(50 \mathrm{mg} / \mathrm{kg})$. The trachea was intubated, and mice were artificially ventilated with an oxygen-nitrogen mixture. One of the femoral arteries was cannulated for recording of arterial pressure and collection of blood samples. Rectal temperature was maintained at $37^{\circ} \mathrm{C}$ using a thermostatically controlled rectal probe connected to a heating lamp. End-tidal $\mathrm{CO}_{2}$, monitored by a $\mathrm{CO}_{2}$ analyzer (Capstar-100; CW I Inc.), was maintained at 2.6-2.7\% $\left(\mathrm{pCO}_{2}=33-35 \mathrm{mmHg}\right.$; dead-space ventilation included) (Zhang et al., 1997) (Table 1). A small craniotomy $(2 \times 2 \mathrm{~mm})$ was performed to expose the whisker-barrel area of the somatosensory cortex, the dura was removed, and the site was superfused with Ringer's solution $\left(37^{\circ} \mathrm{C}\right.$; $\left.\mathrm{pH} 7.3-7.4\right)$ (Zhang et al., 1997). CBF was continuously monitored at the site of superfusion with a laser-Doppler probe (Vasamedic, St. Paul, MN) positioned stereotaxically on the cortical surface. The right vibrissae were cut to a length of 5-10 $\mathrm{mm}$ and stimulated for 1 min by gently stroking them (3-4 Hz) with a cottontipped applicator. The left vibrissae were cut as short as possible to avoid unwanted stimulation (Adachi et al., 1994). Vibrissal stimulation produced increases in CBF that reached a stable plateau (Fig. 1). CBF increases, expressed as percentage increase, were computed as the ratio of CBF at the level of the plateau and baseline CBF before vibrissal stimulation (Zhang et al., 1997; Yang et al., 1998; Iadecola et al., 1999). Two or three vibrissal stimulation trials, separated by 10 min intervals, were averaged for each experimental condition tested. Zero values for CBF were obtained after the heart was stopped by an overdose of halothane at the end of the experiment.

\section{Cerebral glucose use during vibrissal stimulation}

Cerebral glucose use (CGU) was determined in awake, lightly restrained COX $-2+1+$ and $-/-$ mice by a modification of the ${ }^{14} \mathrm{C}$-2-deoxyglucose (2-DG) method (Sokoloff et al., 1977; Meibach et al., 1980). Under halothane anesthesia, one of the femoral arteries was cannulated and used for recording of arterial pressure (Table 1) and collection of blood samples. Wounds were treated with a $2 \%$ lidocaine ointment and sutured. Mice were allowed to recover from anesthesia for 3-4 hr and placed in a loosely fitting restraining cylinder with an anterior opening to expose the face and whiskers. The right vibrissae were stroked for $1 \mathrm{~min}$ before 2-DG injection. Vibrissal stimulation continued throughout the 45 min measurement period. ${ }^{14} \mathrm{C}$-labeled $2-\mathrm{DG}(20 \mu \mathrm{Ci} / 100 \mathrm{gm}$ in $1 \mathrm{ml}$ of $0.9 \% \mathrm{NaCl}$; NEN, Boston, MA) was injected intraperitoneally, and $\sim 60$ $\mu \mathrm{l}$ of arterial blood were collected $1,5,7,10,15,20,25,35$, and $45 \mathrm{~min}$ later. One blood sample was taken before injection of 2-DG. These sampling times were selected in preliminary experiments to accurately resolve the arterial concentration time course of the tracer. Blood samples were centrifuged and stored on ice. The volume of blood removed was replaced with normal saline. Blood sampling reduced mean arterial pressure from $101 \pm 4 \mathrm{mmHg}$ to $70 \pm 6$ in $\mathrm{COX}-2+/+$ mice and from $106 \pm 4$ to $68 \pm 4$ in COX-2 $-/-$ mice $(p<0.05)$. However, such hypotension is unlikely to lead to cerebral hypoperfusion because arte- 

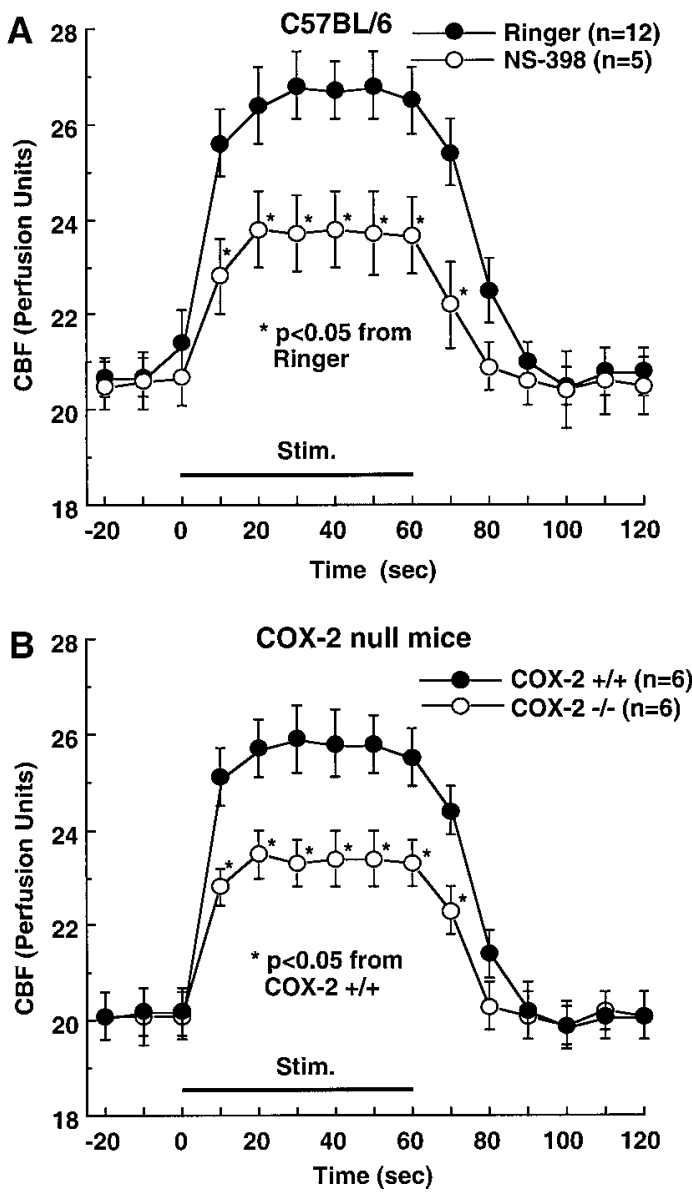

Figure 1. Time course of the increase in CBF produced by vibrissal stimulation (Stim.) after topical application of NS-398 $(A)$ and in COX-2 null mice $(B)$. Vibrissal stimulation produces increases in CBF that reach a plateau after $10-20 \mathrm{sec}$ of stimulation. The increase in CBF is attenuated by topical superfusion with NS-398 $(100 \mu \mathrm{M})(A)$ or in COX-2 null mice $(B)(\mathrm{p}<0.05 ; t$ test $)$.

rial pressure is still within the autoregulated range of $\mathrm{CBF}$ in this preparation (Niwa et al., 1999).

Techniques for determination of tissue 2-DG concentration by quantitative autoradiography have been described previously (Iadecola and $\mathrm{Xu}, 1994)$ and are only summarized. After collection of the last blood sample, mice were deeply anesthetized with halothane and decapitated. Brains were rapidly removed and frozen in isopentane cooled to $-30^{\circ} \mathrm{C}$. Serial sections $(20 \mu \mathrm{m})$ were cut through the brain using a cryostat (Hacker-Bright; Hacker Instruments, Fairfield, NJ), mounted on glass slides, and apposed to x-ray film (Sterling Diagnostic Imaging Inc., Newark, DE) together with calibrated ${ }^{14} \mathrm{C}$ standards (Iadecola et al., 1996). Fourteen days later, the film was developed, and the optical density (OD) of regions of interest was determined bilaterally on four adjacent sections using a computerized image analyzer (MCID system; Imaging Research Inc., St. Catharines, Ontario, Canada). OD was transformed in ${ }^{14} \mathrm{C}$ concentration (nanocuries per gram) using the standards on the film (Iadecola and Xu, 1994). Radioactivity (nanocuries per gram) of plasma samples was determined by liquid scintillation counting (Iadecola and $\mathrm{Xu}, 1994)$. Plasma glucose was measured using a glucose analyzer (Beckman Instruments, Fullerton, CA) (Table 1). CGU ( $\mu \mathrm{mol} /$ $100 \mathrm{gm} / \mathrm{min}$ ) was calculated from the OD of the regions of interest and the arterial time course of 2-DG using the equation developed by Sokoloff et al. (1977).

\section{Experimental protocol for $C B F$ studies}

Effect of NS-398 on the increase in CBF produced by vibrissal stimulation in $C 57 B L / 6$ mice. The cranial window was superfused with Ringer's, and baseline CBF responses to vibrissal activation were obtained. The super- fusion solution was then changed to Ringer's containing increasing concentrations of the COX-2 inhibitor NS-398 (10-300 $\mu \mathrm{M}$; Cayman Chemicals, Ann Arbor, MI) (Futaki et al., 1993; Seibert et al., 1994). Responses to whisker stimulation were tested after each concentration of NS-398 was applied for $40 \mathrm{~min}$. This time point was selected on the basis of preliminary experiments in which the time course of the effect of NS-398 on CBF responses to vibrissal stimulation was studied (data not shown).

Effect of NS-398 on the increase in CBF produced by other vasodilators in $C 57 B L / 6$ mice. The cranial window was superfused with Ringer's, and baseline CBF responses to topical application of acetylcholine (ACh) (10 $\mu \mathrm{M}$; Sigma, St. Louis, MO) or bradykinin (BK) $(50 \mu \mathrm{M}$; Sigma) were tested. Agents were superfused on the cerebral cortex for 3-5 min at concentrations that produce $50 \%$ of maximal responses (Iadecola et al., 1999). The vasodilation produced by arterial hypercapnia was also tested. Hypercapnia $\left(\mathrm{pCO}_{2}=50-60 \mathrm{mmHg}\right.$ ) was produced by introducing $\mathrm{CO}_{2}$ through the circuit of the ventilator and was induced for 2-3 min. After the hypercapnia challenge was completed, $\mathrm{pCO}_{2}$ was returned to normocapnia.

Increases in $C B F$ produced by vibrissal stimulation in $C O X-2$ null mice. In these experiments, the vibrissae were stimulated in COX-2 $-/-$ and $\mathrm{COX}-2+/+$ mice, and the evoked changes in $\mathrm{CBF}$ were recorded. $\mathrm{CBF}$ responses to topical application of $\mathrm{ACh}$ or BK or to arterial hypercapnia were studied using methods described above. In some experiments, the effect of NS-398 on the CBF response evoked by vibrissal stimulation was tested in COX-2 $+/+$ and $-/-$ mice. NS-398 was applied for 40 min at a concentration of $100 \mu \mathrm{M}$.

\section{Data analysis}

Data in text and figures are expressed as means \pm SE. Two-group comparisons were analyzed by the two-tailed $t$ test for independent samples. Multiple comparisons were evaluated by the ANOVA and Tukey's test. $p<0.05$ was considered statistically significant.

\section{RESULTS}

\section{Effect of NS-398 on the increase in CBF produced by vibrissal stimulation}

In these experiments, we studied the effect of the COX-2 inhibitor NS-398 on the increases in CBF produced by vibrissal stimulation in C57BL/6 mice. During superfusion with Ringer's, vibrissal stimulation increased CBF in the contralateral somatosensory cortex by $30 \pm 1 \%(n=6)$, an increase comparable with that reported previously in this preparation (Ma et al., 1996). The increases in CBF reached a stable plateau within 10-20 sec of stimulation (Fig. 1). Superfusion with NS-398 (10-300 $\mu \mathrm{M})$ did not influence resting CBF [before NS-398 $(100 \mu \mathrm{M}), 20.7 \pm 0.5$ perfusion units; after NS-398, $20.6 \pm 0.7 ; p>0.05]$, but it attenuated the increase in $\mathrm{CBF}$ produced by vibrissal stimulation substantially (Figs. 1, 2). The effect of NS-398 was dosedependent and reached a maximum at $100 \mu \mathrm{M}(-47 \pm 7 \% ; p<$ $0.01)$. In contrast, NS-398 did not alter the flow increase produced by hypercapnia $(p>0.05)$ (Fig. 2$)$ or by topical application of ACh and BK $(p>0.05)$ (Fig. 3).

\section{Effect of vibrissal stimulation on CBF in COX-2 null mice}

To provide additional evidence that COX-2 is involved in the flow response evoked by somatosensory activation, COX-2 null mice were studied. In $\mathrm{COX}-2-/-$ mice, the increase in $\mathrm{CBF}$ produced by vibrissal stimulation was markedly reduced compared with COX $-2+/+$ littermates $(-37 \pm 2 \%$ ) (Figs. 1, 4). However, the increases in $\mathrm{CBF}$ produced by hypercapnia or topical application of ACh and BK were not affected (Figs. 4, 5). In COX-2 +/ + , topical superfusion of NS-398 $(100 \mu \mathrm{M})$ reduced the $\mathrm{CBF}$ response to vibrissal stimulation $(-37 \pm 1 \% ; p<0.01)$ (Fig. 4) without attenuating responses to hypercapnia, $\mathrm{ACh}$, or BK (Figs. 4, 5) ( $p>0.05)$. However, in COX-2 - /- mice, NS-398 

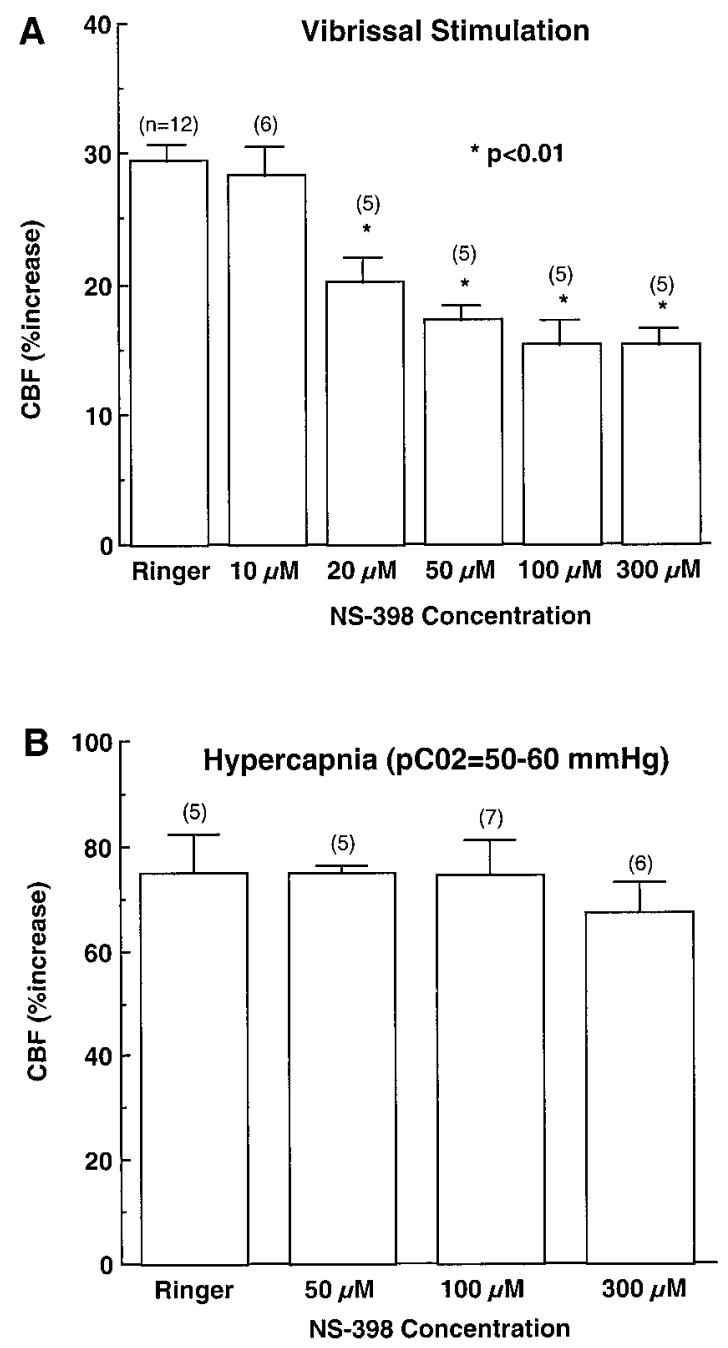

Figure 2. Effect of the COX-2 inhibitor NS-398 on the increases in neocortical CBF produced by vibrissal stimulation $(A)$ or hypercapnia $(B)$. NS-398 was topically superfused on the exposed somatosensory cortex, and CBF was recorded by laser-Doppler flowmetry. NS-398 attenuates the increase in CBF produced by vibrissal stimulation $(A)(p<$ 0.01; ANOVA and Tukey's test) but does not affect the response to hypercapnia $(B)(p>0.05)$.

failed to influence the CBF response to somatosensory activation (Fig. 4).

\section{Effect of vibrissal stimulation on CGU in COX-2 null mice}

In $\mathrm{COX}-2+/+$ mice, $\mathrm{CGU}$ ranged from $64 \pm 7 \mu \mathrm{mol} / 100$ $\mathrm{gm} / \mathrm{min}$ in the left corpus callosum to $260 \pm 38$ in the left inferior colliculus (Table 2, COX-2 $+/+$ column). Vibrissal stimulation increased $\mathrm{CGU}$ selectively in the contralateral somatosensory cortex $(+39 \pm 5 \%)$, contralateral ventrobasal thalamus $(+41 \pm$ $11 \%)$, and ipsilateral trigeminal nucleus $(+54 \pm 15 \%)(p<0.01)$ (Table 2). In COX-2 $-/-$ mice, resting CGU was not different from that of COX $-2+/+$ mice in any of the brain regions studied (Fig. 6, Table 2) $(p>0.05)$. Furthermore, the increases in CGU in somatosensory relay nuclei were similar to those observed in COX-2 +/+ mice (Table 2).

\section{DISCUSSION}

We sought to determine whether the prostanoid-synthesizing enzyme $\mathrm{COX}-2$ is involved in the increases in $\mathrm{CBF}$ produced by
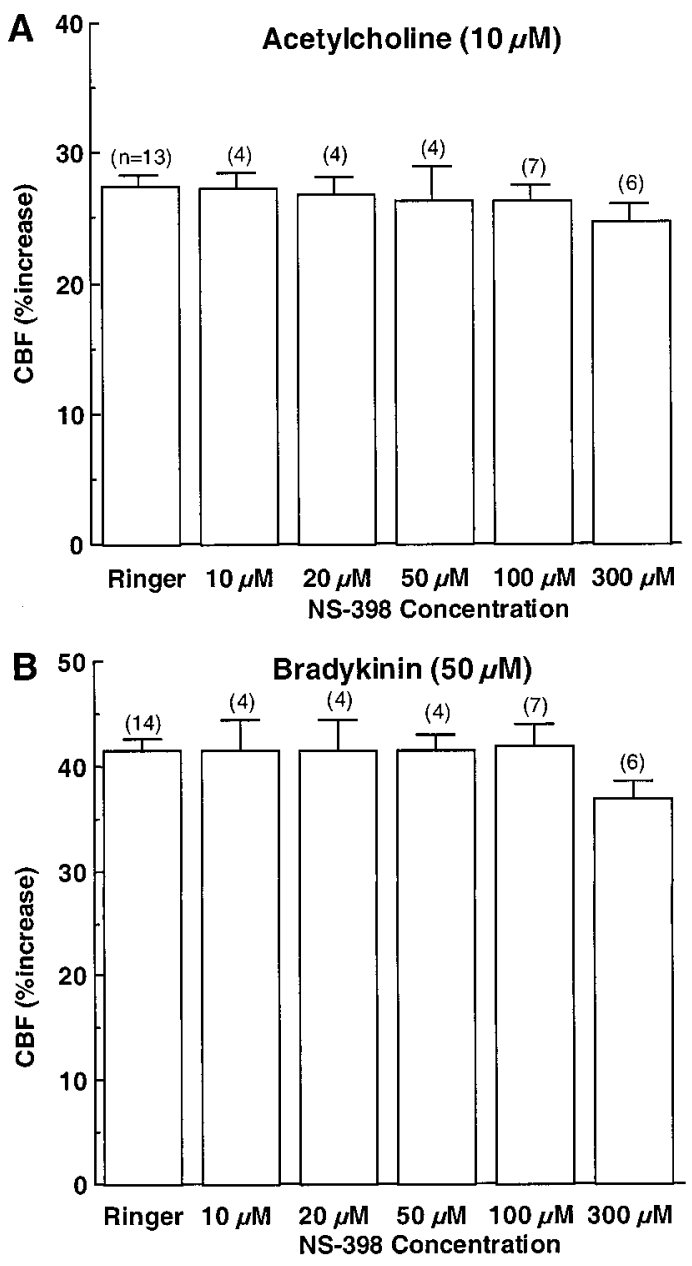

Figure 3. Effect of NS-398 on the increase in CBF produced by topical application of the endothelial-dependent vasodilators acetylcholine $(A)$ or bradykinin $(B)$.

functional activation. Using a mouse model of somatosensory activation, we found that the COX-2 inhibitor NS-398 attenuates the increase in somatosensory cortex blood flow produced by vibrissal stimulation. The attenuation is related to the concentration of the inhibitor and is independent of effects on resting CBF. Interestingly, NS-398 did not attenuate the increase in CBF produced by hypercapnia, a response that is not linked to neural activity (Iadecola et al., 1987; Fabricius and Lauritzen, 1994). Furthermore, NS-398 did not alter the increase in CBF produced by topical application of $\mathrm{ACh}$ or $\mathrm{BK}$, vasodilators that act by releasing vasoactive factors from the endothelium (Rosenblum, 1986; Mayhan, 1996; Sobey and Faraci, 1997; Sobey et al., 1997). The findings indicate that NS-398 attenuates vasodilator responses mediated by neural activation, and they are consistent with the exclusive neuronal localization of COX-2 in the normal brain (Yamagata et al., 1993; Breder et al., 1995; Kaufmann et al., 1996).

To provide independent evidence that COX-2 is involved in the mechanisms of functional hyperemia, mice with a null mutation of the COX-2 gene were studied (Morham et al., 1995). We found that the increase in $\mathrm{CBF}$ produced by vibrissal stimulation is attenuated in COX-2 $-/-$ mice, whereas responses to hypercapnia and to topical application of $\mathrm{ACh}$ or $\mathrm{BK}$ were preserved. To rule out the possibility that the attenuation in functional 

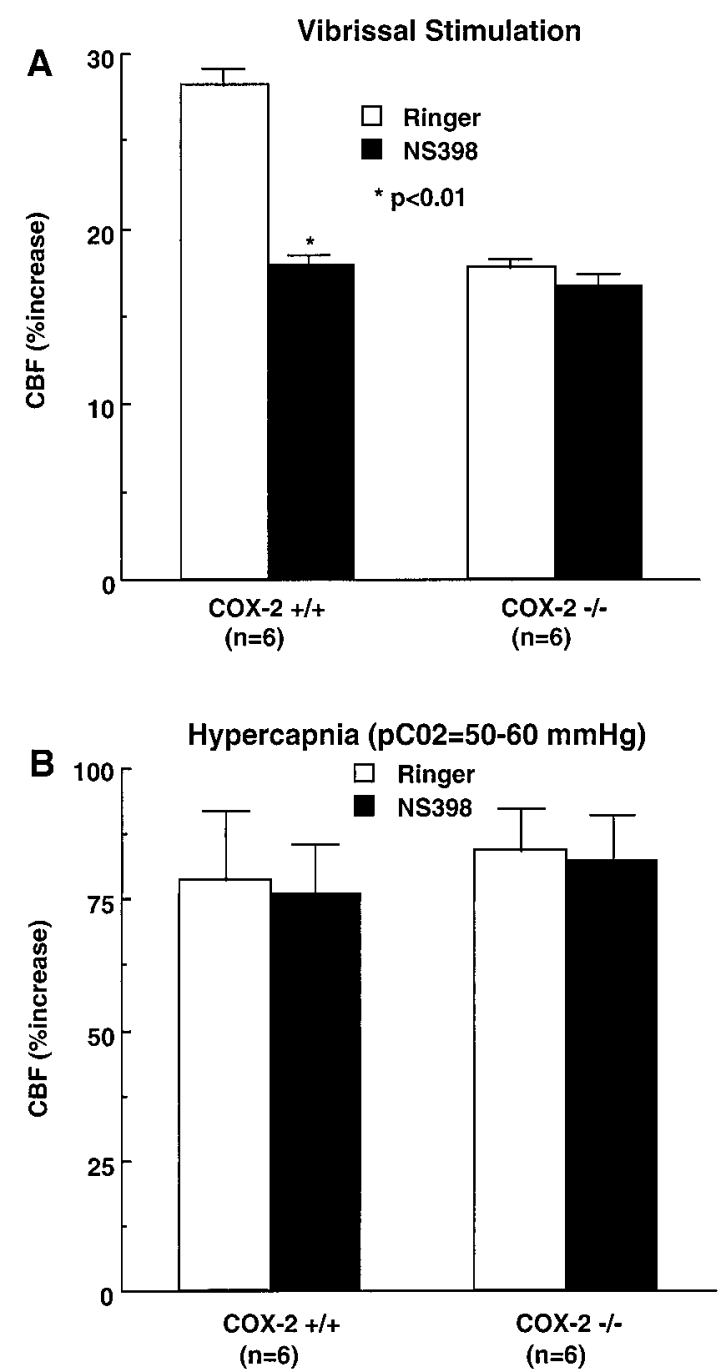

Figure 4. Effect of NS-398 on the increases in CBF produced by vibrissal stimulation $(A)$ or hypercapnia $(B)$ in homozygous COX-2 null mice $(-/-)$ or in wild-type littermates $(+/+)$. The response to whisker stimulation is attenuated in COX-2 null mice $(p<0.01)$. Furthermore, NS-398 $(100 \mu \mathrm{M})$ attenuated the response in COX-2 $+/+$ but not in COX-2 $-/-$ mice. The response to hypercapnia $(B)$ is not affected in COX-2 $-/-$ null mice and is not attenuated by NS-398 in either COX-2 $-/-$ or $+/+$ mice $(p>0.05)$.

hyperemia resulted from a reduction in neural activation during vibrissal stimulation, we studied the effect of vibrissal stimulation on CGU, a reliable marker of synaptic activity (Yarowsky et al., 1983). It was found that the increase in CGU in the whiskerbarrel cortex and in other somatosensory relay stations did not differ between COX $-2+/+$ and $-/-$ mice. Therefore, the attenuation in functional hyperemia in COX $-2-/-$ mice cannot be attributed to a reduction in the intensity of neural activation. However, the possibility that the time course of the activation differs between COX $-2+/+$ and $-/-$ mice cannot be ruled out, because the 2-DG method has a limited temporal resolution. Thus, the 2-DG method provides an average of CGU during the 45 min measurement period, albeit heavily weighted toward the first 10 min (Sokoloff et al., 1977). The findings in COX-2 null mice, in concert with the pharmacological data with NS-398, provide strong evidence that COX-2 is involved in the mechanisms coupling synaptic activity to blood flow in brain.
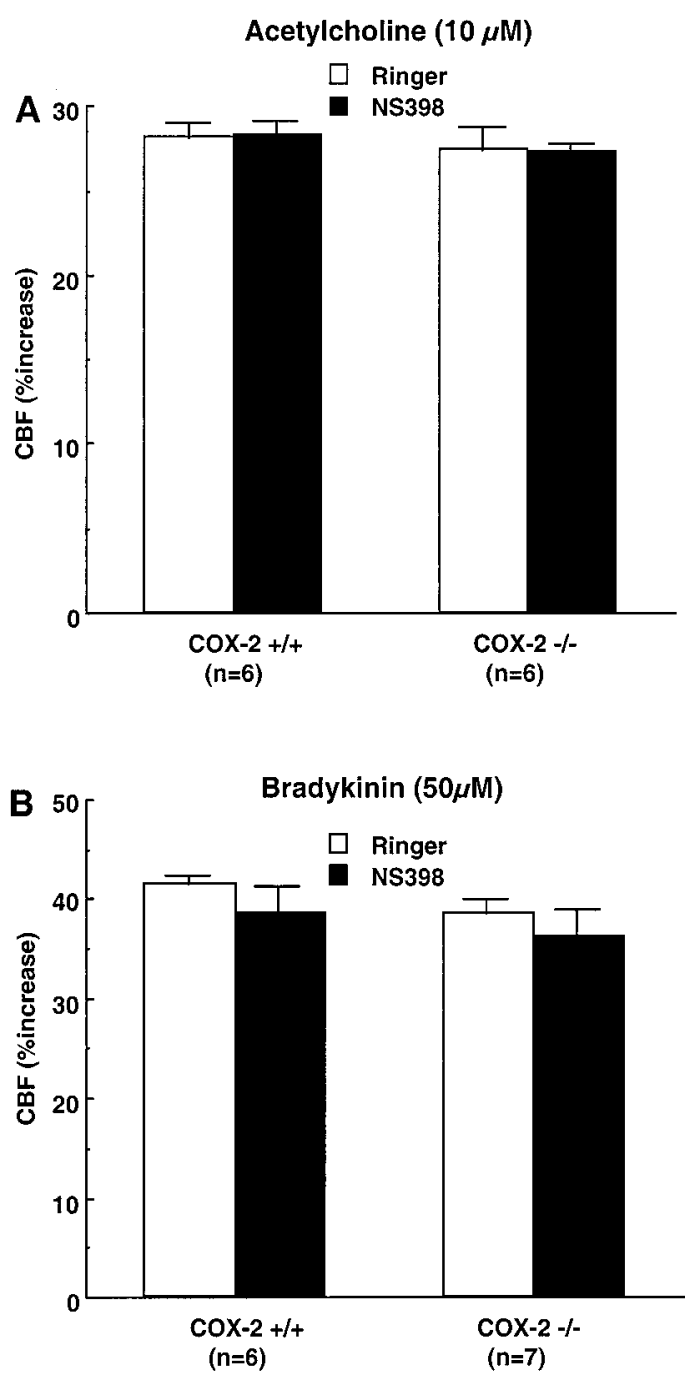

Figure 5. Effect of NS-398 on the increases in CBF produced by acetylcholine $(A)$ or bradykinin $(B)$ in homozygous COX-2 null mice $(-/-)$ or in wild-type littermates. These responses are not affected in COX-2 -/null mice and are not attenuated by NS-398 $(100 \mu \mathrm{M})$ in either COX-2 $-/-$ or $+/+$ mice $(p>0.05)$.

The findings of the present study cannot be attributed to secondary effects on CBF resulting from differences in physiological variables. Arterial pressure and blood gases were carefully monitored and did not differ among the groups of mice studied. In addition, the effect of NS-398 is unlikely to result from a nonspecific blockade of all vasodilator responses, because this inhibitor did not attenuate the CBF response to hypercapnia, ACh, or BK. Furthermore, the observation that NS-398 does not alter the increase in CBF produced by vibrissal stimulation in COX-2 null mice supports the selectivity and specificity of the effects of NS-398 in this model. A major drawback of studies using null mice is that compensatory changes initiated by the missing gene product may alter the normal physiology of the mouse (Gerlai, 1996). Furthermore, because most null mice have a mixed genetic background (C57BL/6 and SV129), the possibility that the observed effects result from strain differences cannot be ruled out (Choi, 1997). However, these concerns do not apply to the present study, because acute pharmacological inhibition of COX-2 reproduced in full the cerebrovascular "phenotype" of the COX-2 null 


\begin{tabular}{|c|c|c|c|}
\hline \multirow{2}{*}{$\begin{array}{l}\text { Region } \\
\text { Somatosensory pathways }\end{array}$} & & \multicolumn{2}{|c|}{ Cerebral glucose use } \\
\hline & & $\mathrm{COX}-2+/+$ & $\mathrm{COX}-2-1-$ \\
\hline \multirow[t]{2}{*}{ Trigeminal $\mathrm{n}$. } & L (Contralateral) & $129 \pm 13$ & $129 \pm 10$ \\
\hline & $\mathrm{R}$ (Stimulated) & $199 \pm 19^{*}$ & $201 \pm 15^{*}$ \\
\hline \multirow[t]{2}{*}{ Ventrobasal thalamic n. } & $\mathrm{L}$ & $206 \pm 16^{*}$ & $202 \pm 8^{*}$ \\
\hline & $\mathrm{R}$ & $146 \pm 11$ & $142 \pm 6$ \\
\hline \multirow[t]{2}{*}{ Somatosensory cortex } & $\mathrm{L}$ & $179 \pm 7^{*}$ & $172 \pm 9^{*}$ \\
\hline & $\mathrm{R}$ & $129 \pm 5$ & $125 \pm 8$ \\
\hline \multicolumn{4}{|l|}{ Forebrain } \\
\hline \multirow[t]{2}{*}{ Frontal cortex } & $\mathrm{L}$ & $129 \pm 8$ & $129 \pm 10$ \\
\hline & $\mathrm{R}$ & $130 \pm 10$ & $129 \pm 12$ \\
\hline \multirow[t]{2}{*}{ Auditory cortex } & $\mathrm{L}$ & $152 \pm 9$ & $151 \pm 6$ \\
\hline & $\mathrm{R}$ & $151 \pm 9$ & $152 \pm 5$ \\
\hline \multirow[t]{2}{*}{ Visual cortex } & $\mathrm{L}$ & $126 \pm 4$ & $125 \pm 5$ \\
\hline & $\mathrm{R}$ & $129 \pm 4$ & $124 \pm 4$ \\
\hline \multirow[t]{2}{*}{ Anterior thalamic $\mathrm{n}$. } & $\mathrm{L}$ & $151 \pm 12$ & $154 \pm 10$ \\
\hline & $\mathrm{R}$ & $153 \pm 10$ & $156 \pm 10$ \\
\hline \multirow[t]{2}{*}{ Hypothalamus } & $\mathrm{L}$ & $85 \pm 11$ & $90 \pm 12$ \\
\hline & $\mathrm{R}$ & $89 \pm 11$ & $89 \pm 11$ \\
\hline \multirow[t]{2}{*}{ Hippocampus } & $\mathrm{L}$ & $88 \pm 9$ & $82 \pm 8$ \\
\hline & $\mathrm{R}$ & $89 \pm 8$ & $82 \pm 9$ \\
\hline \multirow[t]{2}{*}{ Caudate putamen } & $\mathrm{L}$ & $160 \pm 16$ & $147 \pm 12$ \\
\hline & $\mathrm{R}$ & $160 \pm 14$ & $146 \pm 13$ \\
\hline \multirow[t]{2}{*}{ Globus pallidus } & $\mathrm{L}$ & $88 \pm 10$ & $88 \pm 12$ \\
\hline & $\mathrm{R}$ & $88 \pm 10$ & $86 \pm 12$ \\
\hline \multirow[t]{2}{*}{ Corpus callosum } & $\mathrm{L}$ & $64 \pm 7$ & $67 \pm 5$ \\
\hline & $\mathrm{R}$ & $65 \pm 6$ & $66 \pm 6$ \\
\hline \multicolumn{4}{|l|}{ Hindbrain } \\
\hline \multirow[t]{2}{*}{ Superior colliculus } & $\mathrm{L}$ & $159 \pm 13$ & $154 \pm 10$ \\
\hline & $\mathrm{R}$ & $160 \pm 12$ & $149 \pm 11$ \\
\hline \multirow[t]{2}{*}{ Inferior colliculus } & $\mathrm{L}$ & $260 \pm 38$ & $256 \pm 30$ \\
\hline & $\mathrm{R}$ & $258 \pm 38$ & $262 \pm 30$ \\
\hline \multirow[t]{2}{*}{ Pontine gray matter } & $\mathrm{L}$ & $107 \pm 9$ & $109 \pm 9$ \\
\hline & $\mathrm{R}$ & $109 \pm 9$ & $109 \pm 8$ \\
\hline \multirow[t]{2}{*}{ Medullary reticular formation } & $\mathrm{L}$ & $116 \pm 6$ & $113 \pm 11$ \\
\hline & $\mathrm{R}$ & $121 \pm 7$ & $117 \pm 11$ \\
\hline \multicolumn{4}{|l|}{ Cerebellum } \\
\hline Vermis & & $121 \pm 11$ & $113 \pm 8$ \\
\hline \multirow{2}{*}{ Cerebellar hemisphere } & $\mathrm{L}$ & $91 \pm 8$ & $91 \pm 11$ \\
\hline & $\mathrm{R}$ & $94 \pm 9$ & $92 \pm 11$ \\
\hline \multirow[t]{2}{*}{ Dentate n. } & $\mathrm{L}$ & $178 \pm 14$ & $165 \pm 10$ \\
\hline & $\mathrm{R}$ & $177 \pm 13$ & $168 \pm 11$ \\
\hline
\end{tabular}

Mean $\pm \mathrm{SE} ; n=6,{ }^{*} p<0.01$ from opposite side (paired $t$ test). L, Left; R, right.

mice. Therefore, the reduced $\mathrm{CBF}$ response to vibrissal stimulation in COX-2 null mice cannot be attributed to heterogeneity of the genetic background or to compensatory changes in cerebrovascular physiology resulting from $\mathrm{COX}-2$ deletion. In addition, the fact that acute COX-2 inhibition with NS-398 reproduces the cerebrovascular effects of COX-2 deletion rules out the possibility that alterations in neuronal development resulting from lack of COX-2 are responsible for the reduction in the hyperemic response.

The mechanisms regulating the cerebral circulation during synaptic activity have been investigated extensively over the past century. The prevailing view is that working brain cells release vasoactive agents that spread to local blood vessels and produce vasodilation (Iadecola, 1993; Woolsey et al., 1996). Over the years, a wide variety of factors, including $\mathrm{H}+$ and $\mathrm{K}^{+}$ions, $\mathrm{CO}_{2}$, hypoxia, adenosine, neurotransmitters, and neuropeptides, have been proposed to play a role in the coupling between synaptic activity and blood flow (Kuschinsky et al., 1972; Leniger-Follert, 1984; Yaksh et al., 1987; Ko et al., 1990) (for review, see Edvinsson et al., 1993). However, as discussed in detail previously (Edvinsson et al., 1993; Iadecola, 1993; Lou et al., 1987), conclusive evidence that these agents are involved in the vasodilation initiated by functional activity is lacking. Recently, neurons containing nitric oxide synthase (NOS) have been proposed to be involved in the mechanisms coupling synaptic activity to blood flow (Gally et al., 1990; Iadecola, 1993). Initial observations supported this hypothesis by demonstrating that pharmacological inhibition of NOS in somatosensory cortex attenuates the in- 


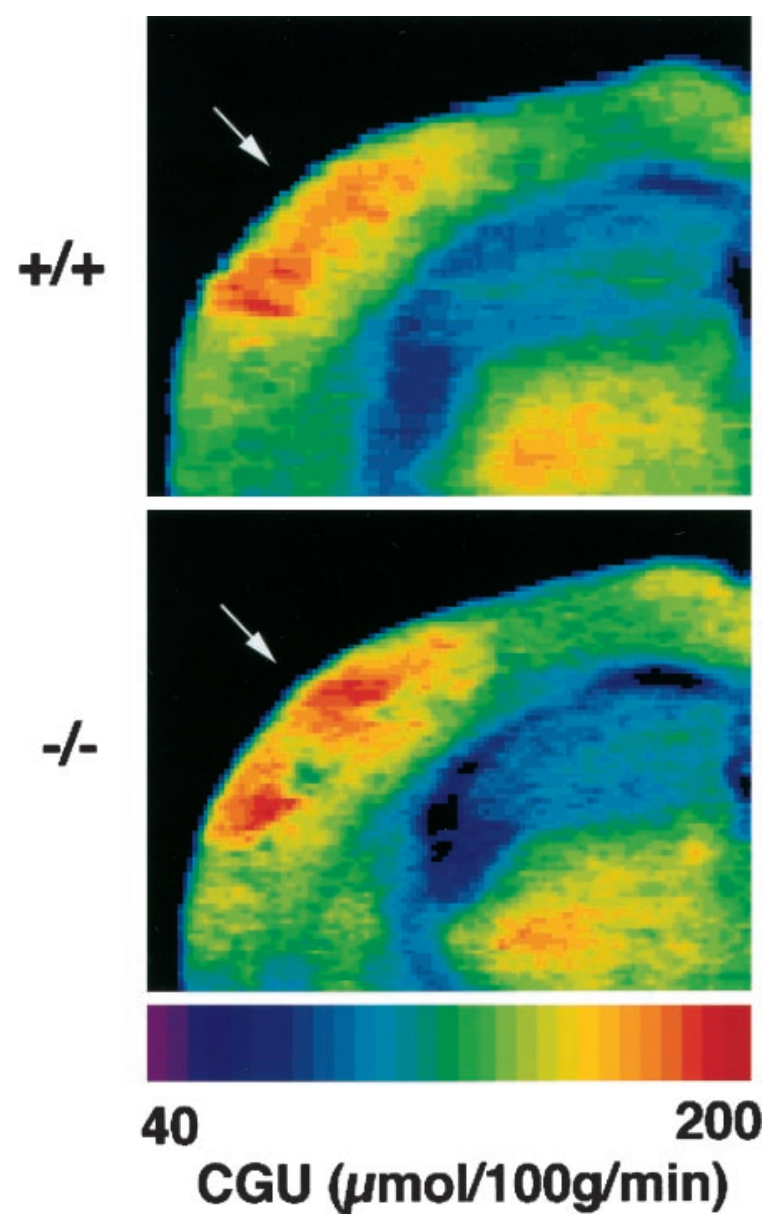

Figure 6. Effect of vibrissal stimulation on CGU in the somatosensory cortex of COX-2 null mice. Vibrissal stimulation produces comparable increases in CGU in COX-2 wild-type $(+/+)$ and null $(-/-)$ mice. See Table 2 for group values.

crease in CBF produced by vibrissal stimulation (Northington et al., 1992; Dirnagl et al., 1993; Irikura et al., 1994). However, subsequent findings have challenged this idea. Mutant mice lacking neuronal NOS (nNOS) have a normal neocortical flow increase in response to vibrissal stimulation (Ma et al., 1996), suggesting that nNOS is not required for the hyperemic response. Furthermore, other studies have indicated that NO acts more as a "permissive" factor, facilitating the action of other vasodilators, than as the mediator of vasodilation (Niwa et al., 1993; Lindauer et al., 1999) (for review, see Iadecola, 1999). Therefore, the presence of $\mathrm{NO}$ is not an absolute requirement for the $\mathrm{CBF}$ increases evoked by synaptic activity.

In contrast, we have shown here that acute inhibition of COX-2 by NS-398 and deletion of COX-2 by gene-targeting approaches produce comparable attenuations of the increase in CBF evoked by somatosensory activation. Therefore, the presence of COX-2 is absolutely required for the full expression of the vasodilation. These data demonstrate that COX-2 plays a critical role in the mechanisms coupling synaptic activity to blood flow and provide functional evidence for a participation of COX-2 in activitydependent processes in the CNS.

The mechanisms by which COX-2 influences CBF during neural activity remain to be defined. In the normal rodent brain, COX-2 is expressed exclusively in neurons (Yamagata et al., 1993; Breder et al., 1995; Kaufmann et al., 1996). It is, therefore, likely that neuronal COX-2 is involved in the coupling between synaptic activity and blood flow. One possibility is that COX-2 is activated during neuronal depolarization and that $\mathrm{COX}-2$ reaction products, either directly or through another agent, influence vascular tone and produce vasodilation. Prostaglandin E2 and prostacyclin, metabolites of the COX-2 reaction product prostaglandin H2 (Brock et al., 1999), or superoxide, the other product of COX-2, are potent cerebrovasodilators (Ellis et al., 1979; Leffler and Busija, 1987; Wei et al., 1996). It would also be of interest to determine whether neurons containing COX-2 have close associations with cerebral blood vessels. For example, central neurons containing NOS, dopamine, $\mathrm{ACh}$, and vasoactive intestinal polypeptide have processes closely apposed to cerebral blood vessels (Eckenstein and Baughman, 1984; Iadecola et al., 1993; Vaucher and Hamel, 1995; Krimer et al., 1998). However, most morphological data on the localization of COX-2 in neurons were obtained in rats, and it would be important to determine whether a similar localization is present also in other species. Irrespective of the specific COX-2 reaction product(s) involved in the vasodilation and the relationships of COX-2 neurons to blood vessels, the present results are noteworthy because they provide, for the first time, evidence that COX-2 is involved in the mechanisms regulating CBF during synaptic activity.

In conclusion, we have demonstrated that pharmacological inhibition of COX-2 with NS-398 attenuates the increase in CBF produced by somatosensory activation. The increase in CBF is also attenuated in mice lacking COX-2. Vasodilator responses of the cerebral circulation that do not depend on neuronal activity were not influenced by NS-398 and were preserved in COX-2 null mice. The attenuation of the CBF response in null mice cannot be attributed entirely to a reduction in the intensity of activation produced by vibrissal stimulation. The findings unveil a critical role of COX-2 in the mechanisms coupling synaptic activity to neocortical blood flow and provide an insight into one of the functions of constitutive COX-2 in the CNS.

\section{REFERENCES}

Adachi K, Takahashi S, Melzer P, Campos KL, Nelson T, Kennedy C, Sokoloff L (1994) Increases in local cerebral blood flow associated with somatosensory activation are not mediated by NO. Am J Physiol 267:H2155-H2162.

Breder CD, Dewitt D, Kraig RP (1995) Characterization of inducible cyclooxygenase in rat brain. J Comp Neurol 355:296-315.

Brock TG, McNish RW, Peters-Golden M (1999) Arachidonic acid is preferentially metabolized by cyclooxygenase-2 to prostacyclin and prostaglandin E2. J Biol Chem 274:11660-11666.

Choi DW (1997) Background genes: out of sight, but not out of brain. Trends Neurosci 20:499-500.

Dirnagl U, Lindauer U, Villringer A (1993) Role of nitric oxide in the coupling of cerebral blood flow to neural activation in rats. Neurosci Lett 149:43-46.

Dubois RN, Abramson SB, Crofford L, Gupta RA, Simon LS, Van De Putte LB, Lipsky PE (1998) Cyclooxygenase in biology and disease. FASEB J 12:1063-1073.

Eckenstein F, Baughman R (1984) Two types of cholinergic innervation in the cortex, one colocalized with vasoactive intestinal polypeptide. Nature 309:153-155.

Edvinsson L, MacKenzie ET, McCulloch J (1993) Cerebral blood flow and metabolism, pp 683. New York: Raven.

Ellis EF, Wei EP, Kontos HA (1979) Vasodilation of cat cerebral arterioles by prostaglandins D2, E2, G2, and I2. Am J Physiol 237:H381-H385.

Fabricius M, Lauritzen M (1994) Examination of the role of nitric oxide for the hypercapnic rise of cerebral blood flow in rats. Am J Physiol 266:H1457-H1464.

Fox PT, Raichle ME (1984) Stimulus rate dependence of regional cere- 
bral blood flow in human striate cortex, demonstrated by positron emission tomography. J Neurophysiol 51:1109-1120.

Futaki N, Yoshikawa K, Hamasaka Y, Arai I, Higuchi S, Iizuka H, Otomo S (1993) NS-398, a novel non-steroidal anti-inflammatory drug with potent analgesic and antipyretic effects, which causes minimal stomach lesions. Gen Pharmacol 24:105-110.

Gally JA, Montague PR, Reeke GNJ, Edelman GM (1990) The NO hypothesis: possible effects of a short-lived, rapidly diffusible signal in the development and function of the nervous system. Proc Natl Acad Sci USA 87:3547-3551.

Gerlai R (1996) Gene-targeting in neuroscience: the systemic approach. Trends Neurosci 19:188-189.

Ginsberg MD, Dietrich WD, Busto R (1987) Coupled forebrain increases of local cerebral glucose utilization and blood flow during physiological stimulation of a somatosensory pathway in the rat: demonstration by double-label autoradiography. Neurology 37:11-19.

Greenberg J, Hand P, Sylvestro A, Reivich M (1979) Localized metabolicflow couple during functional activity. Acta Neurol Scand 72:12-13.

Iadecola C (1993) Regulation of the cerebral microcirculation during neural activity: is nitric oxide the missing link? Trends Neurosci 16: $206-214$.

Iadecola C (1999) The role of NO in cerebrovascular regulation and stroke. In: The haemodynamic effects of nitric oxide (Mathie RT, Griffith TM, eds), pp 202-225. London: Imperial College.

Iadecola C, Xu X (1994) Nitro-L-arginine attenuates hypercapnic cerebrovasodilation without affecting cerebral metabolism. Am J Physiol 266:R518-R525.

Iadecola C, Arneric S, Baker H, Tucker L, Reis D (1987) Role of local neurons in the cerebrocortical vasodilation elicited from cerebellum. Am J Physiol 252:R1082-R1091.

Iadecola C, Beitz AJ, Renno W, Xu X, Mayer B, Zhang F (1993) Nitric oxide synthase-containing neural processes on large cerebral arteries and cerebral microvessels. Brain Res 606:148-155.

Iadecola C, Li J, Yang G, Xu S (1996) Neural mechanisms of blood flow regulation during synaptic activity in cerebellar cortex. J Neurophysiol 75:940-950.

Iadecola C, Zhang F, Niwa K, Eckman C, Turner SK, Fischer E, Younkin S, Borchelt DR, Hsiao KK, Carlson GA (1999) SOD1 rescues cerebral endothelial dysfunction in mice overexpressing amyloid precursor protein. Nat Neurosci 2:157-161.

Irikura K, Maynard KI, Moskowitz MA (1994) The importance of nitric oxide synthase inhibition to the attenuated vascular responses induced by topical L-nitroarginine during vibrissal stimulation. J Cereb Blood Flow Metab 14:45-48.

Kaufmann WE, Worley PF, Pegg J, Bremer M, Isakson P (1996) COX-2, a synaptically induced enzyme, is expressed by excitatory neurons at postsynaptic sites in rat cerebral cortex. Proc Natl Acad Sci USA 93:2317-2321.

Ko KR, Ngai AC, Winn RH (1990) Role of adenosine in regulation of regional cerebral blood flow in sensory cortex. Am J Physiol 259:H1703-H1708.

Krimer LS, Muly III EC, Williams GV, Goldman-Rakic PS (1998) Dopaminergic regulation of cerebral cortical microcirculation. Nat Neurosci 1:286-289.

Kuschinsky W, Wahl M, Bosse O, Thurau K (1972) Perivascular $\mathrm{K}^{+}$and $\mathrm{pH}$ as determinants of local pial arterial diameter in cats: a microapplication study. Circ Res 31:240-247.

Leffler CW, Busija DW (1987) Prostanoids and pial arteriolar diameter in hypotensive newborn pigs. Am J Physiol 252:H687-H691.

Leniger-Follert E (1984) Mechanisms of regulation of cerebral microflow during bicuculline-induced seizures in anesthetized cats. J Cereb Blood Flow Metab 4:150-165.

Lindauer U, Megow D, Matsuda H, Dirnagl U (1999) Nitric oxide: a modulator, but not a mediator, of neurovascular coupling in rat somatosensory cortex. Am J Physiol 277:H799-H811.

Lou HC, Edvinsson L, MacKenzie ET (1987) The concept of coupling blood flow to brain function: revision required? Ann Neurol 22:289-297.

Ma J, Ayata C, Huang PL, Fishman MC, Moskowitz MA (1996) Regional cerebral blood flow response to vibrissal stimulation in mice lacking type I NOS gene expression. Am J Physiol 270:H1085-H1090.

Mayhan WG (1996) Role of activation of bradykinin B2 receptors in disruption of the blood-brain barrier during acute hypertension. Brain Res 738:337-341.
Meibach RC, Glick SD, Ross DA, Cox RD, Maayani S (1980) Intraperitoneal administration and other modifications of the 2-deoxy-D-glucose technique. Brain Res 195:167-176.

Morham SG, Langenbach R, Loftin CD, Tiano HF, Vouloumanos N, Jennette JC, Mahler JF, Kluckman KD, Ledford A, Lee CA, Smithies O (1995) Prostaglandin synthase 2 gene disruption causes severe renal pathology in the mouse. Cell 83:473-482.

Niwa K, Lindauer U, Villringer A, Dirnagl U (1993) Blockade of nitric oxide synthesis in rats strongly attenuates the CBF response to extracellular acidosis. J Cereb Blood Flow Metab 13:535-539.

Niwa K, Carlson GA, Hsiao KK, Iadecola C (1999) Cerebrovascular autoregulation is profoundly impaired in transgenic mice overexpressing the amyloid precursor protein. J Cereb Blood Flow Metab 19:S649.

Northington FJ, Matherne GP, Berne RM (1992) Competitive inhibition of nitric oxide synthase prevents the cortical hyperemia associated with peripheral nerve stimulation. Proc Natl Acad Sci USA 89:6649-6652.

Raichle ME (1987) Circulatory and metabolic correlates of brain function in normal humans. In: The nervous system. Vol 5, Higher functions of the brain, Pt 2 (Plum F, eds), pp 643-674. Bethesda, MD: American Physiological Society.

Raichle ME (1998) Behind the scenes of functional brain imaging: a historical and physiological perspective. Proc Natl Acad Sci USA 95:765-772.

Rosenblum WI (1986) Endothelial dependent relaxation demonstrated in vivo in cerebral arterioles. Stroke 17:494-497.

Seibert K, Zhang Y, Leahy K, Hauser S, Masferrer J, Perkins W, Lee L, Isakson P (1994) Pharmacological and biochemical demonstration of the role of cyclooxygenase 2 in inflammation and pain. Proc Natl Acad Sci USA 91:12013-12017.

Sobey CG, Faraci FM (1997) Effects of a novel inhibitor of guanylyl cyclase on dilator responses of mouse cerebral arterioles. Stroke 28:837-843.

Sobey CG, Heistad DD, Faraci FM (1997) Mechanisms of bradykinininduced cerebral vasodilatation in rats. Evidence that reactive oxygen species activate $\mathrm{K}^{+}$channels. Stroke 28:2290-2294.

Sokoloff L, Reivich M, Kennedy C, Des Rosiers M, Patlak G, Pettigrew K, Sakurada O, Shinohara M (1977) The $\left[{ }^{14} \mathrm{C}\right]$ deoxyglucose method for the measurement of local cerebral glucose utilization: theory, procedure, and normal values in the conscious and anesthetized albino rat. J Neurochem 28:897-916

Vane JR, Bakhle YS, Botting RM (1998) Cyclooxygenases 1 and 2. Annu Rev Pharmacol Toxicol 38:97-120.

Vaucher E, Hamel E (1995) Cholinergic basal forebrain neurons project to cortical microvessels in the rat: electron microscopic study with anterogradely transported Phaseolus vulgaris leucoagglutinin and choline acetyltransferase immunocytochemistry. J Neurosci 15:7427-7441.

Wei EP, Kontos HA, Beckman JS (1996) Mechanisms of cerebral vasodilation by superoxide, hydrogen peroxide, and peroxynitrite. Am J Physiol 271:H1262-H1266.

Woolsey TA, Rovainen CM (1991) Wisker barrels: a model for direct observation of changes in the cerebral microcirculation with neural activity. In: Brain work and mental activity (Lassen NA, Ingvar DH, Raichle ME, eds), pp 189-200. Copenhagen: Munksgaard.

Woolsey TA, Rovainen CM, Cox SB, Henegar MH, Liang GE, Liu D, Moskalenko YE, Sui J, Wei L (1996) Neuronal units linked to microvascular modules in cerebral cortex: response elements for imaging the brain. Cereb Cortex 6:647-660.

Yaksh TL, Wang J-Y, Go VLG, Harty GJ (1987) Cortical vasodilatation produced by vasoactive intestinal polypeptide (VIP) and by physiological stimuli in the cat. J Cereb Blood Flow Metab 7:315-326.

Yamagata K, Andreasson KI, Kaufmann WE, Barnes CA, Worley PF (1993) Expression of a mitogen-inducible cyclooxygenase in brain neurons: regulation by synaptic activity and glucocorticoids. Neuron 11:371-386.

Yang G, Feddersen RM, Zhang F, Clark HB, Beitz AJ, Iadecola C (1998) Cerebellar vascular and synaptic responses in transgenic mice with Purkinje cell dysfunction. Am J Physiol 274:R529-R540.

Yarowsky P, Kadekaro M, Sokoloff L (1983) Frequency-dependent activation of glucose utilization in the superior cervical ganglion by electrical stimulation of cervical sympathetic trunk. Proc Natl Acad Sci USA 80:4179-4183.

Zhang F, Eckman C, Younkin S, Hsiao KK, Iadecola C (1997) Increased susceptibility to ischemic brain damage in transgenic mice overexpressing the amyloid precursor protein. J Neurosci 17:7655-7661. 